dispersal ; weed dispersal by machinery ; the present position concerning the law ; the Ministry approval scheme for herbicides ; and woody weeds with particular reference to the British Colonies. In addition, reports will be presented by research workers from many sources on new herbicides, mixed herbicides and herbicides plus nutrient or crop-protection agents, total herbicides, mode of action of herbicides, experimental techniques, weed control in horticultural crops, grasses and legumes, and the winter spraying of cereals. Accommodation at the Majestic Hotel must be booked before October 4. A Conference registration fee of $£ 2$ 10s. will be charged which will include a copy of the proceedings. All communications should be addressed to the Conference Treasurer, Mr. W. A. Williams, Association of British Insecticide Manufacturers, Cecil Chambers, 86 Strand, London, W.C.2.

\section{Fourth World Forestry Congress, Dehra Dun}

THE Fourth World Forestry Congress will be held in Dehra Dun at the Indian Forestry Institute during December 11-22. The occasion will be of noteworthy interest in that this will be the first time that the Congress will have been held outside Europe, and although some aspects of the utilization of tropical timbers have been considered at previous Congresses, this will be the first one at which special emphasis will be laid on tropical forestry. The discussion on tropical sylviculture will also include the control of desert areas and problems arising from shifting cultivation in various parts of the tropics. In general, the theme of the Congress will be on the land economy and economic development of the country as a whole. Besides visits to forest areas in India, arrangements have also been made for the delegates to make tours in Pakistan. Further information regarding the Congress can be obtained from the Inspector-General of Forests, Ministry of Agriculture, New Delhi.

\section{The Night Sky in September}

FULL moon occurs on Sept. 12d. 20h. 19m., U.T., and new moon on Sept. $27 \mathrm{~d} .00 \mathrm{~h} .50 \mathrm{~m}$. The following conjunctions with the moon take place: Sept. 1d. 15h., Venus $3^{\circ}$ N. ; Sept. 2d. 14h., Saturn $7^{\circ}$ N.; Sept. 7d. 10h., Mars $3^{\circ}$ S. ; Sept. 21d. 16h., Jupiter $1^{\circ}$ N. ; Sept. 29d. 08h., Mercury $3^{\circ}$ N.; Sept. 30d. 02h., Saturn $7^{\circ}$ N. ; Sept. 30d. 22h., Venus $1^{\circ}$ S. In addition to these conjunctions with the moon, Jupiter is in conjunction with Pollux on Sept. 12d. 14h., Jupiter $6.7^{\circ} \mathrm{S}$.; Venus is in conjunction with Saturn on Sept. 16d. 03h., Venus $6 \cdot 1^{\circ} \mathrm{S}$.; Mercury is in conjunction with Spica on Sept. 23d. 17h., Mercury $0 \cdot 6^{\circ} \mathrm{N}$. Mercury is too close to the sun throughout September to be seen. Venus is an evening star, setting at $19 \mathrm{~h} .50 \mathrm{~m} ., 19 \mathrm{~h} .10 \mathrm{~m}$. and $18 \mathrm{~h} .25 \mathrm{~m}$. at the beginning, middle and end of the month, respectively. The visible portion of the illuminated disk rapidly decreases from 0.513 to 0.341 , but owing to the decrease in the planet's distence from the earth-from 67 to 46 millions of miles--the stellar magnitude increases from $-4 \cdot 0$ to $-4 \cdot 2$. Mars, an evening star, sets at $22 \mathrm{~h}$. $50 \mathrm{~m} ., 22 \mathrm{~h} .30 \mathrm{~m}$. and $22 \mathrm{~h}$. $15 \mathrm{~m}$. on September 1, 15 and 30 , respectively : the planet's fairly large declination south-about $26^{\circ}$ renders it rather unfavourable for observation in the British Isles. Jupiter rises at $0 \mathrm{~h} .50 \mathrm{~m}$., $0 \mathrm{~h} .10 \mathrm{~m}$. and $23 \mathrm{~h} .25 \mathrm{~m}$. at the beginning, middle and end of the month, respectively ; its easterly movement in the constellation Gemini is easily seen, and this movement will continue until the middle of November.
Saturn sets at $20 \mathrm{~h} .40 \mathrm{~m} ., 19 \mathrm{~h} .45 \mathrm{~m}$. and $18 \mathrm{~h} .50 \mathrm{~m}$. on September 1, 15 and 30, respectively, but in the last case only about an hour after sunset. It is easily recognized in the constellation Virgo and is a little brighter than a first-magnitude star; its easterly movement takes it into the constellation Libra about the middle of the month. Occultations of stars brighter than magnitude 6 are as follows, observations being made at Greenwich: Sept. $20 \mathrm{~d}$. 02h. 59.9m., $36 B$ Gemi. $(R)$; Sept. 24d. 04h. $29 \cdot 9 \mathrm{~m} ., \pi$ Leon. $(R)$; $R$ refers to reappearance. Autumnal equinox occurs on Sept. 23d. 14h.

\section{Announcements}

The first Drummond Fellowship in nutrition has been awarded to Dr. Iain MacIntyre at the Postgraduate Medical School of London. The Drummond Fellowships are endowed from the proceeds of a recent appeal in memory of the late Sir Jack Drummond.

IN order to deal with the numerous inquiries that are received for advice on the prevention of corrosion of ferrous metals, the British Iron and Steel Research Association has formed a Corrosion Advice Bureau, which will be at 140 Battersea Park Road, London, S.W.11. Dr. J. C. Hudson has been appointed head of the Bureau, Mr. E. E. White as secretary, and Dr. W. H. J. Vernon as consultant. The services of the Bureau will normally be free to members of the Association, and also available to others on a feepaying basis.

THe jubilee of the application by Sir Ambrose Fleming for the British patent for his thermionic valve will be celebrated by the Institution of Electrical Engineers on November 16, exactly fifty years after the event. The proceedings will be opened by the Lord President of the Council, the Marquess of Salisbury, and three lectures will be delivered, by Sir Edward Appleton, Prof. G. W. O. Howe and Dr. J. Thomson, respectively, dealing with valves from the earliest developments to the present day. There will also be an exhibition of historical apparatus.

THE Seventeenth International Congress of Industrial Chemistry will be held in Brussels during September 11-19, this being the fifth time that the Congress has met in Belgium. The Congress will include twenty-nine sections grouped under the following ten main headings: general problems. of the chemical industry; fuels; nuclear science; metallurgy ; industrial inorganic chemistry ; cements, building materials, glassware, ceramics and enamels; industrial organic chemistry; foodstuffs and agricultural industries; Colonial problems; and organization (industrial, commercial and professional). Further information can be obtained either from the Secrétariat du Comité d'Organisation, XXVIIème Congrès International de Chimie Industrielle, 32 Rue Joseph II, Brussels, or from the Commission permanente d'Organisation des Congrès de Chimie Industrielle, 28 Rue Saint Dominique, Paris $7 \mathrm{e}$.

W. WATSON AND Sons, Ltd. (313 High Holborn, London, W.C.1), makers of microscopes, optical and scientific instruments, are holding an exhibition on "The Microscope in Industry and Research", in Milton Hall, Deansgate, Manchester, during September 20-25 (10.30 a.m.-7.30 p.m. ; except September 25 , closing at 2 p.m.). Eighteen firms or other organizations are supplying exhibits illustrating the microscope in connexion with various processes. 